\title{
HUBUNGAN KONSENTRASI DENGAN HASIL PUKULAN JARAK JAUH (LONG SROKE) PADA CABANG OLAHRAGA WOODBALL
}

\author{
Sidik Yazid, Nurlan Kusmaedi, Sandey Tantra Paramitha \\ Fakultas Pendidikan Olahraga dan Kesehatan \\ Universitas Pendidikan Indonesia, Jl. Dr. Setiabudhi No. 299 Bandung \\ Em@il: yazid_sidik@gmail.com
}

\begin{abstract}
Abs trak
Dalam olahraga woodball Pukulan jarak jauh (long stoke) merupakan salah satu teknik dasar yang dilakukan dalam kerangka mengutamakan irama dan mengontrol seluruh ayunan, mulai dari backswing, downswing, impact terhadap bola dan follow through. Konsentrasi sangatlah dibutuhkan dalam melakukan long stroke, sehingga irama pukulan kita tidak berubah. Tujuan dalam penelitian ini adalah untuk mengetahui hubungan konsentrasi dengan hasil pukulan jarak jauh (long stroke) pada cabang olahraga woodball. Metode penelitian yang digunakan yaitu korelasional. Sampel yang digunakan sebanyak 20 orang dari atlet woodball UPI yang diambil menggunakan metode purposiv sampling. Instrumen yang digunakan ialah Tes Konsentrasi (Tes Grid Concentration Exercise) dan Tes Pukulan Jarak Jauh (Long Stroke) dengan validitas untuk tes long stroke adalah nilai r $=0,890$ dan $p=0,000$ dengan reliabilitas tesnya adalah 0,722. Hasil penelitian menunjukkan nilai rata-rata dari tes konsentrasi ialah 12,10 dan dari tes pukulan jarak jauh (long stroke) adalah 7,20. Nilai dari uji korelasi kedua variabel yaitu 0.920 dan nilai probabilitas 0,000 , dengan kontribusi $\mathrm{X}$ terhadap $\mathrm{Y}$ sebesar $84,6 \%$ yang berarti terdapat hubungan yang signifikan antara konsentrasi dengan hasi pukulan jarak jauh (long stroke) pada cabang olahraga

Kata kunci: konsentrasi, pukulan jarak jauh (long stroke), woodball..
\end{abstract}

\section{PENDAHULUAN}

Olahraga merupakan salah satu kebutuhan pokok yang perlu diperhatian oleh setiap individu manusia, karena olahraga merupakan aktifitas fisik manusia yang berupaya untuk pembentukan manusia seutuhnya yang sehat jasmani dan rohani serta memiliki mental yang baik. Banyak macam-macam kegiatan olahraga yang dapat kita lakukan baik melalui aktivitas olahraga rekreasi, olahraga kesehatan dan olahraga prestrasi. Bahkan semakin berkembangnya jaman semakin banyak cabang olahraga yang bermunculan, yang merupakan modifikasi dari olahraga yang sudah ada ataupun memang baru.
Cabang olahraga woodball merupakan salahsatu cabang olahraga baru yang memang masih asing dan jarang sekali didengar di lingkungan kita. Olahraga ini ditemukan atau disusun pertama kali oleh Mr. Ming-Hui Weng and Mr. Kuang-Chu Young pada tahun 1990 di Cina Taipei (Kriswanto, 2011, hlm. 5). Permainan Woodball mempunyai karakteristik yang mirip dengan permainan golf. Dimana sasaran dalam permainan ini adalah berusaha memasukkan bola kedalam sasaran yang telah ditentukan dengan sedikit mungkin jumlah pukulan. Sehingga pemenang dalam permainan ini adalah pemain dengan jumlah pukulan paling sedikit dibanding dengan pemain lainnya. 
Olahraga ini sangat memerlukan koordinasi yang baik, selain harus memiliki taktik dan teknik yang baik juga harus mempunyai mental bertanding yang kuat. Pada olahraga woodball dibutuhkan kesabaran dan konsentrasi yang tinggi, misalnya pada saat melakukan pukulan jarak jauh (long stroke), pengendalian konsentrasi sangatlah penting karena apabila konsentrasi hilang pada saat pertandingan bisa berakibat fatal, misalnya pada saat akan melakukan pukulan pertama atau melakukan pukulan jarak jauh (long sroke), perkenaan bola yang dipukul bisa berakibat tidak tepat, sehingga hasil pukulan keluar dari lintasan atau bisa disebut OB (Out Off Baundary). Dalam olahraga woodball ini ayunan atau swing adalah salah satu teknik yang sangat dominan, oleh karena itu atlet yang akan melakukan swing atau ayunan pada saat melakukan pukulan dibutuhkan konsentrasi dan koordinasi yang baik. Apabila seorang atlet tidak bisa mengendalikan ketegangan ketika akan melakukan pukulan, maka otot- otot sekitar tubuhnya menjadi kaku, konsentrasi dan koordinasinya pun menjadi terganggu sehingga hasil pukulan tidak akan maksimal sehingga dapat merusak pola permainan selanjutnya.

Konsentrasi adalah memusatkan perhatian pada suatu hal tertentu dan tidak terganggu oleh stimulus internal maupun eksternal yang tidak relevan, seperti yang dijelaskan oleh Schmid dkk dalam (Komarudin, 2013, hlm. 138). Stimulus internal adalah gangguan sensoris maupun pikiran seperti perasaan lelah, cemas, dan sebagainya. Stimulus eksternal adalah gangguan dari luar diri seperti sorak sorai penonton, ejekan penonton, kesalahan keputusan wasit dan lain-lain. Atlet yang dikatakan memiliki konsentrasi menurut Loehr dalam (Komarudin, 2013, hlm. 139) "we have the right focus when what we are doing is the same as what we are thinking". Maksudnya adalah atlet yang memiliki perhatian yang baik akan melakukan sesuatu yang sama dengan apa yang sedang dipikirkannya..

Pada dunia olahraga, konsentrasi merupakan kemampuan atlet untuk memusatkan perhatian pada informasi yang relevan selama kompetisi. Untuk meraih prestasi yang baik diperlukan konsentrasi yang baik, seperti yang dikemukakan oleh Dalloway yang dikutif dari Lismadiana (2013, hlm. 116) yang menyatakan bahwa "konsentrasi diperlukan untuk meraih prestasi optimal, tidak hanya pada cabang olahraga menembak, panahan, golf, tenis, renang, tetapi hampir pada seluruh cabang olahraga, termasuk olahraga beregu". Dari pernyataan diatas dapat diartikan bahwa setiap cabang olahraga sangatlah memerlukan konsentrasi yang baik. Bahkan dalam cabang olahraga woodball, dimana cabang olahraga ini seperti olahraga golf, yang mana kemampuan dan keahlian tergantung dari diri kita sendiri, karena permainan ini termasuk permainan individu. Bahkan faktor ekternal juga akan mempengaruhi konsentrasi kita saat bertanding, contoh kejadian ketika atlet woodball UPI mengikuti kejuaraan daerah Jawa Barat hasil prestasi mereka bisa dikatakan unggul dari kontingen yang lain, tetapi ketika mengikuti kejuaraan nasional kebanyakkan dari atlet Woodball UPI cenderung menurun, dari kejadian tersebut penulis menyimpulkan bahwa penurunan prestasi atlet Woodball UPI disebabkan oleh tingkat konsentrasi atlet saat bertanding di tingkat nasional menurun karena disebabkan oleh cakupan kejuaraan yang lebih besar dan jumlah penonton pun semakin banyak.

Maka dari itu, dengan adanya kaitan antara konsentrasi terhadap keberhasilan seorang pemain dalam melakukan pukulan jauh (long stroke) dalam permainan woodball yang dapat menunjang pencapaian prestasi olahraga, penulis tertarik untuk meneliti permasalahan ini. Oleh karena itu, penulis mengambil judul sebagai berikut. "Hubungan Konsentrasi dengan Hasil Pukulan Jauh (long stroke) pada Cabang Olahraga Woodball’.

\section{METODE}

Metode penelitian yang digunakan dalam penelitian ini adalah metode penelitian 
kuantitatif, dengan pendekatan deskriptif korelatif. Mengenai metode korelatif Prof. Dr. Hamid Darmin, M.Pd (2012, hlm. 7) menjelaskan bahwa metode penelitian korelatif bertujuan untuk mengetahui ada tidaknya hubungan, dan seberapa jauh hubungan ada antara dua variabel (yang dapat diukur) atau lebih.

Adapun desain penelitian yang peneliti gunakan dalam penelitian ini adalah penelitian korelatif yang akan menyelidiki ada tidaknya hubungan antara variabel bebas dan variabel terikat. Variabel bebas $(\mathrm{X})$ dalam penelitian ini adalah konsentrasi dan variabel terikatnya $(\mathrm{Y})$ adalah hasil pukulan jarak jauh (long stroke).

Sampel yang digunakan dalam penelitian ini adalah 20 orang atlet yang berasal dari UKM Woodball UPI dengan jumlah populasi 40 orang. Pengambilan sampel menggunakan teknik purposive sampling, seperti yang dijelaskan oleh Sugiyono (2013, hlm. 85) "Purposive sampling adalah teknik penentuan sampel dengan pertimbangan tertentu". Adapun pertimbangan - pertimbangan dalam penelitian ini adalah:

Penguasaan teknik dasar pukulan jarak jauh (long stroke) yang baik.

Keikut sertaan (jam terbang) Atlet woodball UPI dalam kejuaraan nasional ataupun daerah.

Waktu dan biaya dalam penelitian.

Dari dasar pertimbangan diatas maka peneliti menentukan jumlah atlet yang akan dijadikan sebagai sampel penelitian yaitu sebanyak 20 orang dari populasi yang telah disebutkan yaitu atlet UKM Woodball UPI.

Pada prinsipnya meneliti adalah melakukan pengukuran terhadap fenomena alam maupun social, maka harus ada alat ukur. Alat ukur dalam penelitian biasanya disebut instrument penelitian. Instrument penelitian yang digunakan dalam penelitian ini adalah:

Tes konsentrasi berupa Tes Concentration Grid Exercise dari Harris and Bette L. Harris p. 189 dalam (Leisure Press,1984: 2), validitas dan reliabilitas instrument ini di adopsi dari penelitian Qodriannisa Puspaningrum (2013) dengan nilai validitas $\mathrm{t}$ table $1,86<\mathrm{t}$ hitung
8,771 tes dikatakan valid. Nilai reliabilitas dengan harga taraf signifikan 0,05 adalah sebesar 0,63 maka $r$ hitung lebih besar dari $r$ table, bisa dikatakan tes reliabel. Apabila merujuk pada tabel koefisien reliabilitas maka nila $r$ hitung $=0,96$ berada dikisaran $0,800-1,00$ yang berarti bahwa reliabilitas sangat tinggi.

Test keterampilan pukulan jarak jauh (long stroke) menurut (Kriswantoro, 2011, hlm. 39), hasil pengujian reliabilitasnya yaitu memiliki nilai Cronbach's Alpha $=0,722>0,600$. maka tes pengukuran tersebut dapat dilanjutkan untuk tes penelitian.

\section{HASIL DAN PEMBAHASAN}

Dari hasil penelitian, peneliti menemkukan norma interprestasi kemampuan tes konsentrasi dan tes pukulan jarak jauh (long stroke), untuk mengetahui nilai hasil kedua tes diantaranya:

Tabel 2

\section{Norma Penilaian Tes Konsentrasi}

\begin{tabular}{ccc}
\hline NO & Kriteria & Keterangan \\
\hline 1 & 21 keatas & Sangat baik \\
\hline 2 & $16-20$ & Baik \\
\hline 3 & $11-15$ & Sedang \\
\hline 4 & $6-10$ & Kurang \\
\hline 5 & 5 kebawah & Sangat kurang \\
\hline
\end{tabular}

Tabel 3

Norma Penilaian Tes Pukulan jarak jauh (long stroke)

\begin{tabular}{cc}
\hline Skala & Nilai \\
\hline$>14$ & Sangat Baik \\
\hline $10-13$ & Baik \\
\hline $5-9$ & Cukup \\
\hline $3-4$ & Kurang \\
\hline$<3$ & Sangat Kurang \\
\hline
\end{tabular}


Dengan didapatkan kedua norma penilaian diatas maka peneliti dapat mengetahui rata rata hasil tes konsentrasi atlet woodball Universitas Pendidikan Indonesia memiliki rata-rata 12,10 dengan nilai tertinggi 24 dan terendah 5, dengan standar deviasi 6,095. Sedangkan, rata-rata dari hasil tes pukulan jarak jauh (long stroke) yaitu 7,20 dengan nilai tertinggi 13 dan nilai terendah 2 , dengan standar deviasi 3,874.

\section{Tabel 4 \\ Deskriptif}

\begin{tabular}{lccccc}
\hline & N & Max & Min & Mean & Std. D \\
\hline $\begin{array}{l}\text { Kons } \\
\text { entra } \\
\text { si }\end{array}$ & 20 & 24,00 & 5,00 & 12,10 & 6,095 \\
\hline $\begin{array}{l}\text { long } \\
\text { strok } \\
\text { e }\end{array}$ & 20 & 13,00 & 2,00 & 7,20 & 3,874 \\
\hline
\end{tabular}

Tabel 5

Uji Correlations

\begin{tabular}{ccc}
\hline $\mathbf{R}$ & Sig. & Keputusan \\
\hline 0.920 & 0.000 & H0 ditolak \\
\hline
\end{tabular}

Pada tabel 5 terlihat bahwa untuk pengujian hipotesis peneliti yaitu terdapat hubungan konsentrasi dengan hasil pukulan jarak jauh (long stroke) pada cabang olahraga woodball hasilnya menunjukkan bahwa nilai signifikansi yaitu $0,000<0,05$, maka Ho ditolak, artinya terdapat hubungan yang signifikan antara konsentrasi dengan hasil pukulan jarak jauh (long stroke) pada cabang olahraga woodball, untuk mengetahui besaran kontibusi variable $\mathrm{X}$ (konsentrasi) terhadap $\mathrm{Y}$ (pukulan jarak jauh) maka peneliti melihat koefisien determinasi sebagai berikut :
Tabel 6 Koefisien Determinasi

\begin{tabular}{cccc}
\hline Model & R & R Square & Adjusted R Square \\
\hline 1 & .920 & .846 & .837 \\
\hline
\end{tabular}

Dari hasil analisis diatas, didapat nilai yang ada pada tabel 6 korelasi antara konsentrasi dengan hasil pukulan jarak jauh (long stroke) menunjukkan angka 0,920 yang artinya terdapat hubungan yang signifikan, dengan nilai $R$ square $0,846>0,05$. Hal ini menunjukkan indeks determinasi, yaitu persentase yang menyumbangkan pengaruh $\mathrm{X}$ terhadap $\mathrm{Y}$. $\mathrm{R}$ square mengandung pengertian bahwa $84,6 \%$ sumbangan $\mathrm{X}$ terhadap $\mathrm{Y}$, sedangkan sisanya sebesar 15,4\% dipengaruhi oleh faktor lain.

\section{KESIMPULAN}

Berdasarkan hasil penelitian dan pembahasan yang telah diuraikan diatas, maka hasil penelitian ini dapat disimpulkan bahwa:

Dapat diketahui dari hasil tes konsentrasi, sampel yang termasuk kriteria "konsentrasi sangat baik" terdapat tiga orang, yang termasuk kriteria "konsentrasi sangat rendah" berjumlah sembilan orang. Dan rata-rata dari hasil tes konsentrasi ialah sebesar 12,10.

Hasil tes pukulan jarak jauh (long stroke) dimana diketahui kriteria "baik" berjumlah empat orang, yang termasuk kriteria "cukup" sembilan orang. Hasil rata-rata dari tes long strok adalah 7,20.

Terdapat hubungan yang signifikan antara konsentrasi dengan pukulan jarak jauh (long stroke) pada cabang olahraga woodball, dimana korelasi antara konsentrasi dengan hasil pukulan jarakjauh (long stroke) pada cabang olahraga woodball. 


\section{DAFTAR PUSTAKA}

Arikunto, Suharsimi. (2006). Prosedur Penelitian Suatu Pendekatan Praktik. Rinekacipta, Jakarta

Darmadi, H. (2013). Metode Penelitian Pendidikan Sosial. Bandung: Afabeta.

Dwiyogo, Wasis \& Kriswantoro. (2009). Olahraga Woodball. Wineka media, Malang

Komarudin. (2013). Psikologi Olahraga: Latihan Mental dalam Olahraga Kompetitif. Bandung: PT. Remaja Rosdakarya Offset.

Kriswantoro. (2011). Teknik Dasar Bermain Woodball. Indonesia Woodball Association, Semarang

Nurhasan \& Cholil D. H. (2007). Modul Tes dan Pengukuran Keolahragaan. Bandung: Jurusan Pendidikan Kepelatihan, Universitas Pendidikan Indonesia.

Puspaningrum, Qodriannisa. (2013). Pengaruh Latihan Meditasi Otogenik Terhadap Peningkatan Konsentrasi Latihan (Studi Eksperimen Terhadap Atlet Karete Kata Kei Shin Kan Bandung). Skripsi Universitas Pendidikan Indonesia.

Suherman, A dan Rahayu, Nur, I. (2014). Modul Statistik untuk Ilmu Keolahragaan. Bandung: Program Studi Ilmu Keolahragaan, Universitas Pendidikan Indonesia

TN. (TH). Improving Your Concentration. [Online]. Tersedia di: http //www.sportnz.org.nz/documents/officials/improving_yourconcentration.pdf [Diakses 24 Juli 2014 Pukul 11.35]. 